\title{
Towards Green Building with Prefabricated Systems on Flat Development in Indonesia
}

\author{
Hary Agus Rahardjo, Priyasambada, and Dwi Dinariana
}

\begin{abstract}
The increase of population in major cities led to the rise in housing need. In line with the growth of the city, the available land in urban areas increasingly limited and expensive. Construction of flats is one solution to meet the housing needs. In practice, many conventional construction methods require lumber for formwork and scaffolding. Excessive consumption of wood has shown to reduce forest cover and damage the environment, which is negatively affecting human life. This paper examines the precast method as an alternative system that can be used. Object of research is done on the construction of flats in the city of Batam, Bantul and Bandung. Result of the discussion suggests that the prefabricated system can save the use of wood, reduce the cost of construction, maintain the environment and also contribute to the green building.
\end{abstract}

Index Terms-Development, flat, green building, prefabricated.

\section{INTRODUCTION}

\section{A. Background}

The population of large cities increased from year to year. This happens in several major cities in Asia such as Tokyo, New Delhi, Beijing, Manila, Bangkok, Jakarta, Singapore, and Kuala Lumpur as shown in the Fig. 1 below [1].

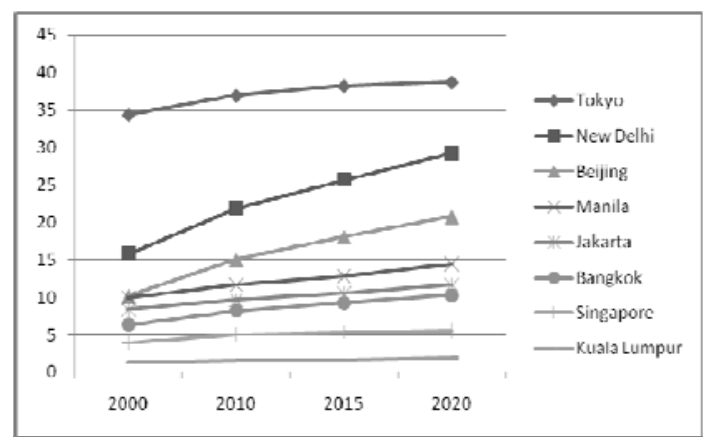

Fig. 1. Population growth in Asia major cities.

The population increase is partly due to the arrival of residents from areas outside the major cities due to various reasons, such as to obtain a higher income, better education, and better health facilities, up to complete existing entertainment facilities as well as the ease live. In line with national economic progress, then other cities such as Bantul, Batam and Bandung are also experiencing growth and therefore the population of those cities is also increasing due to several factors similar to those that occurred in the major

Manuscript received July 9, 2014; revised September 12, 2014.

The authors are with the University of Persada Indonesia (e-mail: rahardjo30@yahoo.com, dwidinariana@yahoo.com). cities [2]-[5]. The population growth in Batam, Bantul and Bandung is pointed out in Fig. 2 as follow. This has led to an increased need for shelter for its residents.

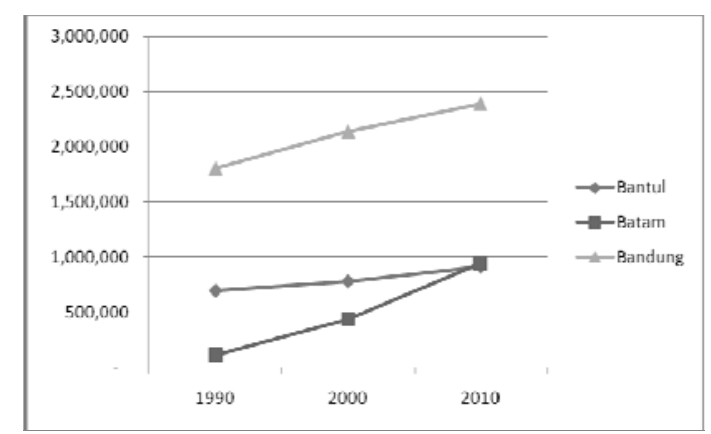

Fig. 2. Population growth in Batam, Bantul and bandung city.

With the passage of time, the development of the city has resulted in limited land for settlement. Increasing land prices restrict citizens to build the settlements horizontally or in the form of landed houses. To meet the needs of residential facilities for its residents, the construction of flats is a solution, because it can utilize a smaller area but can accommodate a lot more number of people to live.

The construction of high-rise building in general and flats in particular, especially in Indonesia, is still frequently used formwork and scaffolding wood to make concrete construction. Fig. 3 below shows construction method using wood as formwork and scaffolding which is known as Conventional System.

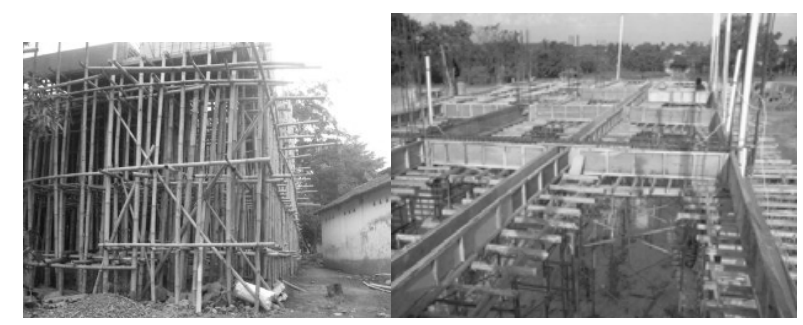

Fig. 3. Conventional system using wood for formwork and scaffolding

The use of wood in large quantities from time to time has reduced timber forest cover in Indonesia. Reduction of forest area is often not accompanied by conservation efforts, such as reforestation. This resulted in significant environmental damage, and can even lead to natural disasters such as floods and landslides during the rainy season.

\section{B. Problem Statement}

Environmental degradation, especially forest areas need to be stopped. Settlement construction should pay attention to environmental aspects. To get to the green building it is necessary to look for alternative construction methods that 
can reduce the volume of wood used in construction work. One way of reducing the use of wood in building construction is the application of precast system. The question is whether the application of precast system can save the use of wood in building materials compared to conventional structural system implementation. How big savings are to be gained. Are there incentives that can be given to developers as the party that undertakes the construction of flats by applying precast structural system? In addition, we examine the contribution of precast structural system to be able to meet the criteria of green building.

\section{Purpose of the Study}

This study is intended to demonstrate that the use of precast systems can reduce the use of wood materials in building construction, compared with conventional systems. In addition, the decrease in the use of the wood will be studied more about saving costs and also assessed the effectiveness of the precast system in supporting the achievement of green building.

\section{Research Method}

This study uses the method of Comparative Quantitative research. The study is based on the philosophy of positivism which emphasizes phenomena objectively and quantitatively assessed. Maximizing the objectivity of the research design was conducted using the figures, as well as processing the figures. Comparative research directed to find out whether there are differences between the two groups in the variables studied. This paper will examine the differences in the amount of wood used for the formwork in a project that uses conventional system and the amount of wood used for the formwork when the project is done with precast system. Precast system used is the PSA system. The research sample included a five-story building, typical building affordable for the people in Indonesia. Sample locations are in the city of Bandung, Batam and Bantul.

\section{LITERATURE REVIEW}

\section{A. Reduction of Forest Area in Indonesia}

Indonesia is a country with the third largest tropical forest in the world after Brazil and Zaire, which is an area of 133.7 million hectares. The vast covering $10 \%$ of the total tropical forest in the world. Indonesia's forest area covering $60 \%$ of the entire territory of Indonesia. Indonesia's forests have an important role. Not only as the lungs of the world, has the source of life and economic development, but also as a counterweight evened global climate [6]. Indonesia experienced a loss of forests or deforestation area of 15.8 million hectares (ha) between 2000 and 2012. Therefore, be the fifth largest country in terms of forest loss as indicated in Fig. 4 below [7].

\section{B. Flats Development in Indonesia}

Flat development in Indonesia is carried out with regard to the arrangement of the urban areas and also to meet the needs of the home for its residents. Rental flats is allocated for the students, police officers, military members, workers, and boarding pupils. In 2011, rental flats built as many as 100 buildings and in 2012 increased to 126 buildings [8]. The shape of rental flats with affordable rental rates can be seen in Fig. 5 as follows.

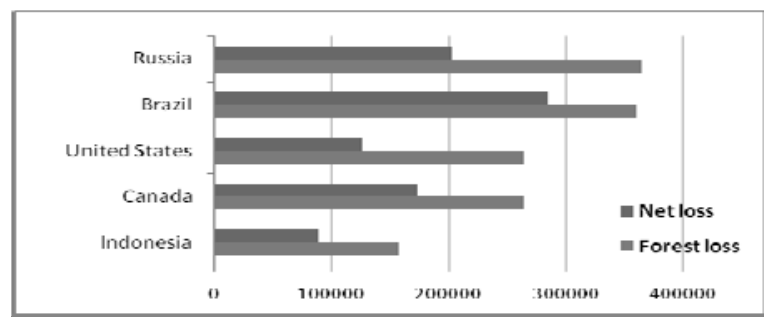

Fig. 4. Forest loss and net loss in the world.

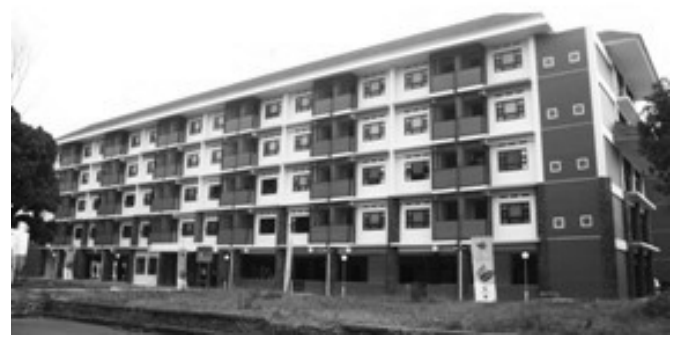

Fig. 5. Affordable rental flat in Indonesia.

\section{Prefabricated Method with PSA System}

PSA precast system is an open system framework structure (open frame) which has a unique connection to the location of the component beams and columns in the column above the rallying point. This system can be used for low-rise buildings to high-rise buildings [9].

PSA precast system consists of three components, namely: column components, beam components and slab components. Overall PSA system precast components can be assembled in fabric or in the field (the project site) as shown in the following Fig. 6.

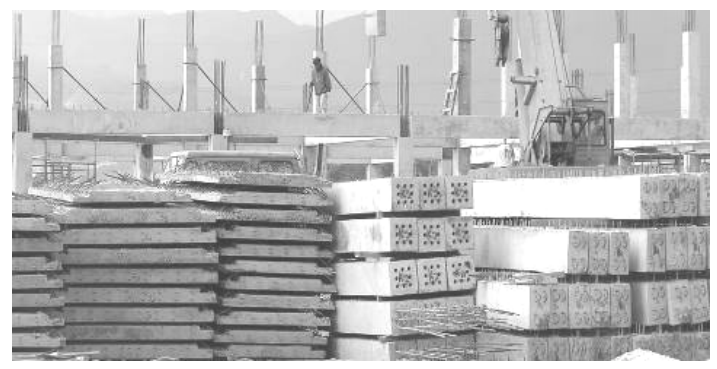

Fig. 6. Prefabricated concrete.
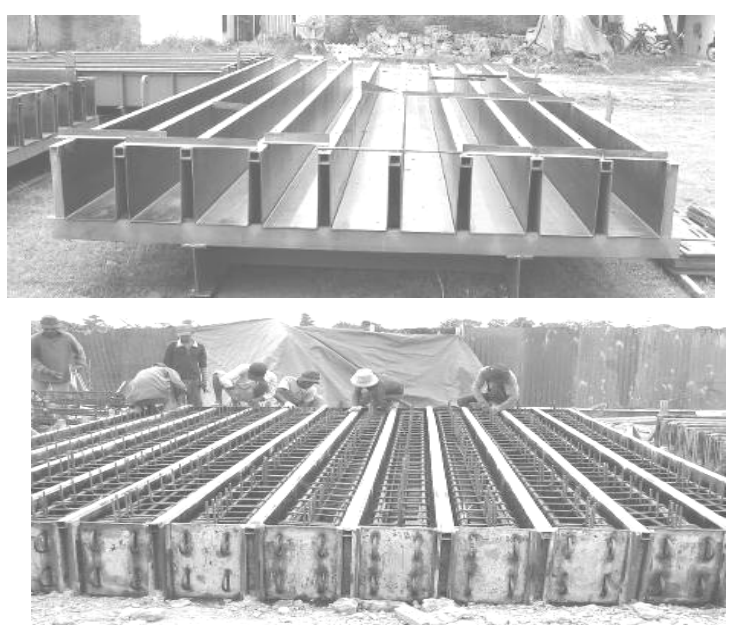

Fig. 7. Molding component of PSA system. 
PSA precast system uses molds made of steel plates that can be used over and over again with a high level of repetitions. The repetition rate will have an impact on the cost of production, where the higher repetition rate will be the lower cost of production [10]. Mold component is a series of elements that can be mounted and opened easily. Molding components can be seen in the Fig. 7 below.

\section{Green Building in Indonesia}

One sector that has a significant contribution in energy consumption, water consumption, and land use, is the building sector [11]. Therefore it is necessary to apply a new paradigm in building construction that is the concept of green buildings.

In the application of the concept of green building, we need a measurable and objective guideline, adapted to the existing environment, and there is regular evaluation to the implementation.

It's all to meet Greenship rating issued by GBCI (Green Building Council of Indonesia), which can meet the existing regulations, among others, saving energy, conserving resources, reducing the burden on the city's infrastructure, and recognition of green building commitment [12]. One of the main aspects that must be considered in building a green building is the use of the material. If we are using materials from nature, then the material must meet the following requirements [13]:

1) Impact to the environment should be a source of renewable energy and sustainable manner.

2) Economic impact, the material must be obtained from local sources/around the project, to reduce transportation costs

3) Social Impact, material containing recycling system to reduce waste products, but still well tested material.

\section{RESUlt AND DisCUSSION}

The following are the results of calculations for the use of timber formwork in Batam city, Bantul and Bandung. The data used comes from Flats Development Project conducted by the Directorate General of Human Settlements, Ministry of Public Works, Strategic Urban Settlements Development Unit, 2012-2013 fiscal years. The data obtained were taken from three locations that use a PSA precast system.

\section{A. Location: Batam City}

Construction of flats in the city of Batam is located in the Top 100 Tembesi, consisting of 2 twin blocks, where each block is a twin five-level building, with four levels of occupancy from the 2 nd floor to the 5 th floor, while the first floor is used as a public facility are.

Execution time was 270 calendar days, the work schedule of the structure completed in 17 weeks.

The wood needs distribution with conventional systems for each building component in Batam location is as shown in the following Fig. 8. In the conventional system shows that the demand for wood for formwork plate is more than $50 \%$ of the total wood, as many as $209.384 \mathrm{~m}^{3}(57 \%)$ of the total $368.55 \mathrm{~m}^{3}$. Meanwhile, the need of wood requirement in the PSA system is as illustrated in the Fig. 9. The total requirement of wood by using precast PSA system compared with conventional methods only by $4.7 \%\left(17: 32 \mathrm{~m}^{3} / 368.55\right.$ $\mathrm{m}^{3}$ ). Comparison of wood needs on location in Batam, for some parts of the building can be seen in Fig. 10.

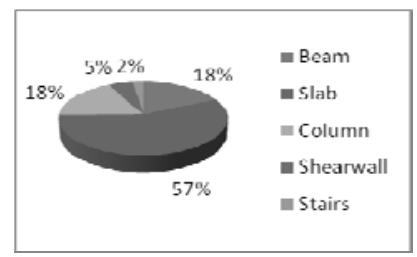

Fig. 8. Conventional system

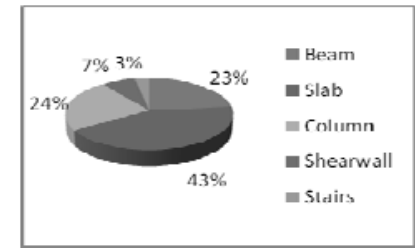

Fig. 9. PSA system.

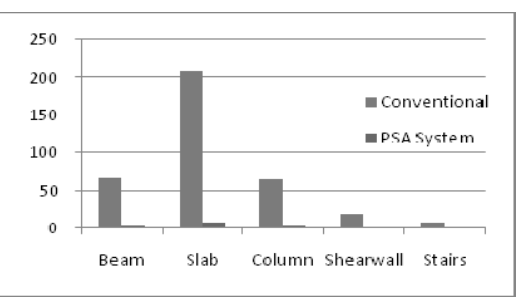

Fig. 10. Comparison of wood needs.

\section{B. Location: Bantul City}

Construction of flats in the city of Bantul is located in Kota Gede, consisting of 1 twin blocks, where each block is a twin five-level building, with four levels of occupancy from the 2nd floor to the 5th floor, while the first floor is used as a public facility area.

Execution time was 210 calendar days, the work schedule of the structure completed in 17 weeks.

The wood needs distribution with conventional systems for each building component in Bantul location is as shown in the following Fig. 11. In the conventional system shows that the demand for wood for formwork plate is more than $50 \%$ of the total wood, as many as $209.384 \mathrm{~m}^{3}(56 \%)$ of the total $372.59 \mathrm{~m}^{3}$. Meanwhile, the need of wood requirement in the PSA system is as illustrated in Fig. 12 below. The total requirement of wood by using precast PSA system compared with conventional methods only by $5.18 \%\left(19: 31 \mathrm{~m}^{3} / 372.59\right.$ $\mathrm{m}^{3}$ ). Comparison of wood needs on location in Bantul, for some parts of the building can be seen in the following Fig. 13.

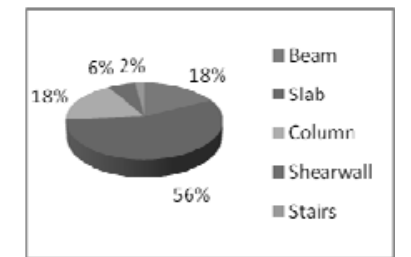

Fig. 11. Conventional system.

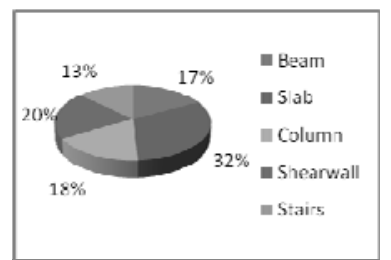

Fig. 12. PSA system.

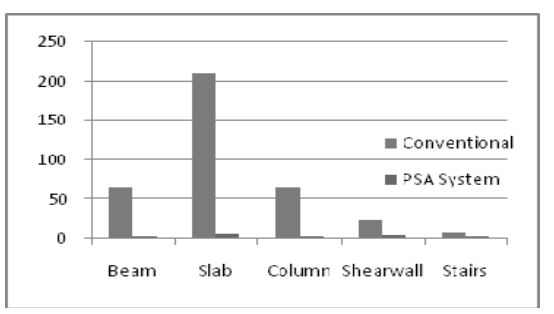

Fig. 13. Comparison of wood needs.

\section{Location: Bandung City}

Construction of flats in the city of Bandung is located in 
Rancaekek, consisting of 1 twin blocks, where each block is a twin five-level building, with four levels of occupancy from the 2 nd floor to the 5th floor, while the first floor is used as a public facility area.

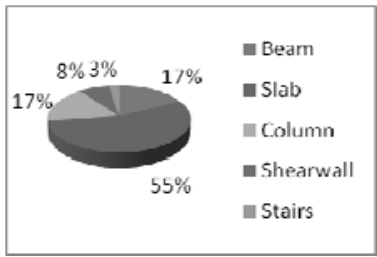

Fig. 14. Conventional system.

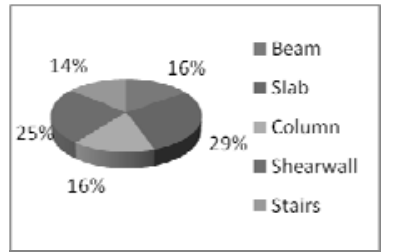

Fig. 15. PSA system.

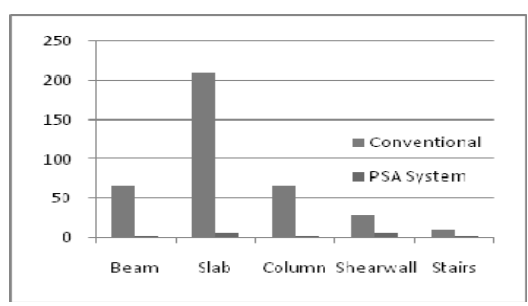

Fig. 16. Comparison of wood needs.

TABLE I: THE AVERAGE AND TOTAL VOLUME OF FORMWORK ON CONVENTIONAL SYSTEM

\begin{tabular}{|c|c|c|c|c|c|c|c|}
\hline \multirow{3}{*}{ No } & \multirow{3}{*}{ Location } & \multicolumn{5}{|c|}{ Volume of wood $\left(\mathrm{m}^{3}\right)$} & \\
\hline & & Beam & Slab & Column & Shearwall & Stairs & \\
\hline & & 1 & 2 & 3 & 4 & 5 & \\
\hline 1 & Batam & 66.157 & $\begin{array}{c}209.38 \\
4\end{array}$ & 65.591 & 19.744 & 7.675 & \\
\hline 2 & Bantul & 66.157 & $\begin{array}{c}209.38 \\
4\end{array}$ & 65.591 & 23.785 & 7.675 & \\
\hline 3 & $\begin{array}{l}\text { Bandun } \\
\mathrm{g}\end{array}$ & 66.157 & $\begin{array}{c}209.38 \\
4\end{array}$ & 65.591 & 28.927 & 9.510 & \\
\hline & OTAL & $\begin{array}{c}198.47 \\
0 \\
\end{array}$ & $\begin{array}{c}628.15 \\
2 \\
\end{array}$ & $\begin{array}{c}196.77 \\
4 \\
\end{array}$ & 72.455 & $\begin{array}{c}24.85 \\
9 \\
\end{array}$ & TOTAL \\
\hline & ERAGE & 66.157 & $\begin{array}{c}209.38 \\
4\end{array}$ & 65.591 & 24.152 & 8.286 & 373.57 \\
\hline
\end{tabular}

TABLE II: THE AVERAGE AND TOTAL VOLUME OF FORMWORK ON PSA SYSTEM

\begin{tabular}{|c|c|c|c|c|c|c|c|}
\hline \multirow{3}{*}{ No } & \multirow{3}{*}{ Location } & \multicolumn{5}{|c|}{ Volume of wood $\left(\mathrm{m}^{3}\right)$} & \\
\hline & & Beam & Slab & Column & Shearwall & Stairs & \\
\hline & & 1 & 2 & 3 & 4 & 5 & \\
\hline 1 & Batam & 4.028 & 7.414 & 4.108 & 1.237 & 0.531 & \\
\hline 2 & Bantul & 3.331 & 6.131 & 3.397 & 3.957 & 2.499 & \\
\hline 3 & $\begin{array}{c}\text { Bandun } \\
\text { g }\end{array}$ & 3.405 & 6.267 & 3.472 & 5.429 & 3.122 & \\
\hline \multicolumn{2}{|c|}{ TOTAL } & $\begin{array}{c}10.76 \\
4\end{array}$ & $\begin{array}{c}19.81 \\
2 \\
\end{array}$ & 10.977 & 10.623 & 6.152 & TOTAL \\
\hline \multicolumn{2}{|c|}{ AVERAGE } & 3.588 & 6.604 & 3.659 & 3.541 & 2.051 & 19.443 \\
\hline
\end{tabular}

TABLE III: THE COST COMPARISON OF WOOD MATERIALS USED

\begin{tabular}{|c|c|c|c|c|}
\hline & System & $\begin{array}{c}\text { Volume } \\
\mathrm{m} 3\end{array}$ & $\begin{array}{c}\text { Unit Price } \\
\text { US\$ }\end{array}$ & $\begin{array}{c}\text { Total } \\
\text { US\$ }\end{array}$ \\
\hline 1 & $\begin{array}{c}\text { Conventiona } \\
1\end{array}$ & 373.57 & 290 & 108,335 \\
\hline 2 & PSA System & 19.44 & 290 & 5,637 \\
\hline
\end{tabular}

Execution time was 210 calendar days, the work schedule of the structure completed in 17 weeks.

The wood needs distribution with conventional systems for each building component in Bantul location is as shown in the following Fig. 14. In the conventional system shows that the demand for wood for formwork plate is more than $50 \%$ of the total wood, as many as $209.384 \mathrm{~m}^{3}(55 \%)$ of the total $379.57 \mathrm{~m}^{3}$. Meanwhile, the need of wood requirement in the PSA system is as illustrated in Fig. 15 below. The total requirement of wood by using precast PSA system compared with conventional methods only by $5.72 \%\left(21: 70 \mathrm{~m}^{3} / 379.57\right.$ $\mathrm{m}^{3}$ ). Comparison of wood needs on location in Bantul, for some parts of the building can be seen in the following Fig.
16.

\section{Cost Saving Analysis of the Usage of Wood Formwork}

From the calculation of the material needs of the wood on the location in Batam, Bantul and Bandung for both systems, the conventional system and the PSA system, it can be calculated on the average usage at each location. Then on the basis of the average consumption, we calculated the total use of wood materials in building the towers.

Table I and Table II below indicated the average and total volume of formwork on conventional system and PSA system.

Table III above [14] shows that the cost of wood materials used to build flats with PSA System is only for $5.2 \%$ of the cost of the use of wood in conventional system.

\section{CONCLUSION}

Precast structural system proved more efficient in the use of wood materials for formwork system compared with a conventional structure. Average use of wood for the conventional system is $373.57 \mathrm{~m}^{3}$ compared with PSA System precast systems which requires only as much as 19.44 $\mathrm{m} 3$ of wood, or of only $5.20 \%$ compared with conventional methods.

By using precast structures that system, the overall cost of housing construction will be cheaper. By taking the average price of lumber grade II US\$290 per $\mathrm{m}^{3}$, then the conventional system would require a fee of US\$108,335 while the PSA System precast structural system costs only US\$5,637. There was a decrease in the cost of Rp. 1.239445 billion, - or US\$103,287. The total cost of the work for 1 twin block structure is Rp. 3.945575 billion,- or US\$328,797 so that there is an impairment charge of $31.41 \%$. Thus, the cost efficiency at the same time is an incentive that can be given to developers of flats building.

Application of PSA System in the public housing development also contributed a sizable number of buildings in the criteria that apply green building. As per the existing criteria, the minimum number that can be achieved is 5 points (from MRC items 5 i.e. fabrication material usage by 3 points and from MRC 6 i.e. items of local material usage, by 2 points) and a maximum of 7 points if the item is added to the material MRC 4 i.e. wood certified usage by 2 points. It is a fairly large number of green building in contributing scores.

Meanwhile Greenship for the building of a new book by GBCI, according to MRC criteria 4, certified wood to get the maximum value of 2 , according to MRC criteria 5 Materials Prefabricated get maximum value 3 , and according to the criteria of the MCR 6 to get the maximum value of 2 .

\section{REFERENCES}

[1] Projection and Estimation of Large City's Population in Asian Countries, World Bank Report, 2010.

[2] Statistical YearBook of Indonesia. Indonesia Center Bureau of Statistic, Catalog BPS: 1101001, August 2012

[3] Batam in Figures, Center Bureau of Statistic Batam City, Catalog BPS: 1101.001.2171, November 2013

[4] Bantul in Figures, Center Bureau of Statistic Bantul City, Catalog BPS: 1102.001.3402, September 2012.

[5] Bandung in Figures, Center Bureau of Statistic Bandung City, Catalog BPS: 1102.001.3273, October 2012. 
[6] Forest Wacth, Indonesia Forest Pictures in period of $2000-2009$.

[7] M. Hansen et al. "High-resolution global maps of 21 st-century forest cover change," Science, vol. 342, no. 6160, 2013, pp. 850-853.

[8] Ministry of Housing, Republic of Indonesia, Report on Performance Acountability of Government Agency, 2012.

[9] Prijasambada, "PSA system, new era in building construction," presented at the National Seminar on Civil Engineering, Jakarta, Indonesia, September 2, 2006.

[10] Prijasambada, "The comparison of construction method in high rise building, PSA system and conventional system," presented at the National Seminar on Building Construction, Threat and Opportunity, Jakarta, Indonesia, March 10, 2008.

[11] Anonim. (2013). [Online]. Available: http://www. Kayulegal.or.id.

[12] Green Building Council Indonesia, Greenship untuk Bangunan Baru Versi 1.2, Jakarta: Divisi Rating dan Teknologi, 2013.

[13] I. Wahyudi. (2013). Concept on Green Building. [Online]. Available: http://www. ilham-wahyudi.weebly.com

[14] Anonim, Cost Calculation Method on Precast Construction on High Rise Building, Indonesia National Standard, Jakarta: 2012.

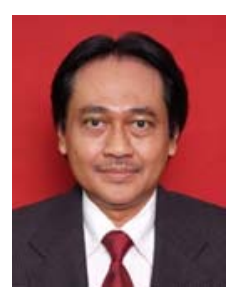

Hary Agus Rahardjo was born in Tegal, Indonesia in 1959. He got his Ph.D. degree in civil engineering from Colorado State University, USA in 2002.

$\mathrm{He}$ is a lecturer in the field of civil engineering and the vice rector at the University of Persada Indonesia, Jakarta. His research area is about Construction and Infrastructure Project Management.

Dr. Rahardjo has publication in Procedia Social and Behavioral Sciences 46 (2012), pp 5497 - 5501,
International Journal of Business and Management Studies, 1(2):315-320, (2012), IACSIT International Journal of Engineering and Technology, 6(2):151-154, 6(3):217-219.

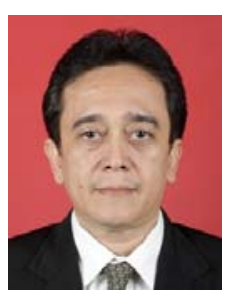

Prijasambada was born in Jakarta, Indonesia in 1963. He got his master of management in Jakarta and also master of civil engineering in Jakarta, Indonesia.

$\mathrm{He}$ is a lecturer in the field of civil engineering and the director of the engineering consultant with the expertise in structural engineering design. He had designed structural aspect of many high rises building built in Indonesia.

Prijasambada has many patents; one of them is PSA system, a system of structural component prefabricated.

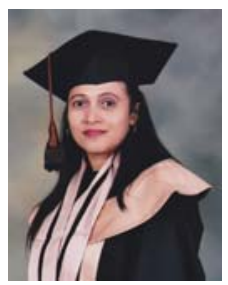

Dwi Dinariana was born in Madiun, Indonesia in 1969. She got her doctorate degree in environmental and natural resources management from IPB, Indonesia in 2011.

She is a lecturer in the field of civil engineering and the head of Department of Civil Engineering Master Program at the University of Persada Indonesia, Jakarta. Her research area is about housing and construction management. 